\title{
A stable starch preparation for amylase determinations
}

\author{
G. P. FRASER AND J. C. B. FENTON \\ From the Department of Chemical Pathology, St Bartholomew's Hospital, London
}

SYNOPSIS Starch readily dissolves in dimethylsulphoxide (DMSO) to give a clear, colourless $\stackrel{\text { i }}{-}$ solution which is stable and forms a convenient stock starch solution for amylase determinations. Dimethylsulphoxide has no inhibitory effect on serum amylase over a wide range of concentrations. $\$$

Instability of starch substrate solutions is a common source of difficulty in the determination of serum amylase in the busy laboratory. This can be overcome by preparing fresh substrate at frequent intervals which is time consuming, and moreover some preparations are not immediately available for emergency estimations if the substrate is found to have deteriorated.

Several preservatives for starch substrates have been suggested, for example, benzoate (Gomori, 1957; Caraway, 1959), sorbic acid (Rice, 1959), methyl and propyl parahydroxybenzoate (Marsters, Kinney, and Lin, 1960). Reif and Nabseth (1962)noted that marked bacterial degradation of starch solutions can occur in the presence of preservatives and suggest that both preservatives and sterile precautions are necessary in preparing and dispensing starch substrates.

The observation that soluble starch can bz dissolved in dimethylsulphoxide to yield a solution which is freely miscible with water led us to investigate the value of this reagent as a stock solution for the preparation of starch substrates. A colorimetric method has been used for the determination of serum amylase (Wootton, 1964; Caraway, 1959) and the results show that dimethylsulphoxide starch is a useful and convenient stock substrate. This solution may be useful also as a stable preparation in the determination of amylase by other techniques.

\section{REAGENTS}

1 STOCK STARCH SOLUTION Soluble starch AR is dried over concentrated sulphuric acid in vacuo. Approximately $70 \mathrm{ml}$ dimethylsulphoxide (B.D.H. Ltd) is added with vigorous stirring to $5.0 \mathrm{~g}$ of the dry starch to give a

Received for publication 19 February 1968. homogeneous suspension. Any lumps formed at this stage dissolve very slowly and become transparent on heating and are thus not easily detected. The suspensions is then heated on a boiling water bath for 30 minutes with vigorous stirring. It is advisable to use a magnetic stirrer with a large follower both for the mixing and heatinge stages. The clear solution is cooled and made up to $100 \mathrm{mb}$ with dimethylsulphoxide (DMSO). After mixing thoroughly it is allowed to stand for 24 hours with furthero occasional mixing.

2 PHOSPHATE BENZOATE BUFFER $p H \quad 7.0$ Disodiumă hydrogen phosphate, $13.3 \mathrm{~g}$, anhydrous $\mathrm{AR}$, and $4.3 \mathrm{~g}$ benzoic acid AR are dissolved in water and made up to $100 \mathrm{ml}$. The $p \mathrm{H}$ is checked and adjusted to $p \mathrm{H} 7.0$ if necessary.

3 WORKING SOLUTION OF BUFFERED STARCH SUBSTRATE Of the stock starch in dimethylsulphoxide, $0.4 \mathrm{ml}$, is diluted to $50 \mathrm{ml}$ with phosphate benzoate buffer. $\mathrm{Al}^{-}$ though this solution keeps for about a month at $4^{\circ} \mathrm{C}$, as does the preparation of Wootton (1964), it is better to make a fresh dilution from stock to avoid the risk of the occasional rapid degradation of starch.

4 Iodine solutions and sodium chloride were used asD described by Wootton (1964).

METHOD

Estimations of amylase activity were made by the methodw of Wootton (1964) using either the substrate described in his method or the substrate prepared as above from stock dimethylsulphoxide starch solution. Because of the reported interference of serum proteins in the starche iodine reaction (Wilding, 1963, 1965; Pimstone, 1964) serum controls were prepared by adding $8.5 \mathrm{ml}$ of wate 5 to $1 \mathrm{ml}$ of starch substrate followed by $0.4 \mathrm{ml}$ of iodinep and $0.1 \mathrm{ml}$ of the diluted serum. Optical densities were measured immediately after colour development in $\mathbb{D}$ 
Unicam S.P. 300 colorimeter using a red filter with maximum transmission at $630 \mathrm{~m} \mu$.

\section{RESULTS}

The introduction of dimethylsulphoxide into an amyloclastic amylase technique might interfere either with the starch-iodine colour reaction or with the hydrolysis of starch by amylase. The first of these possibilities was investigated by adding dimethylsulphoxide to a series of tubes containing different concentrations of starch substrate. After developing the iodine colour, the optical densities were measured and compared with a duplicate series not containing any dimethylsulphoxide. The results are shown in Fig. 1 and demonstrate that dimethylsulphoxide is without significant effect on the starch iodine reaction in the concentration used in the preparation of the starch substrate $(0.8 \mathrm{ml}$ DMSO/ $100 \mathrm{ml}$ substrate).

EFFECT OF DIMETHYLSULPHOXIDE ON THE HYDROLYSIS OF STARCH BY AMYLASE Starch substrate prepared by the method of Wootton (1964), but having double the normal concentrations of starch and buffer, was diluted with varying amounts of dimethylsulphoxide

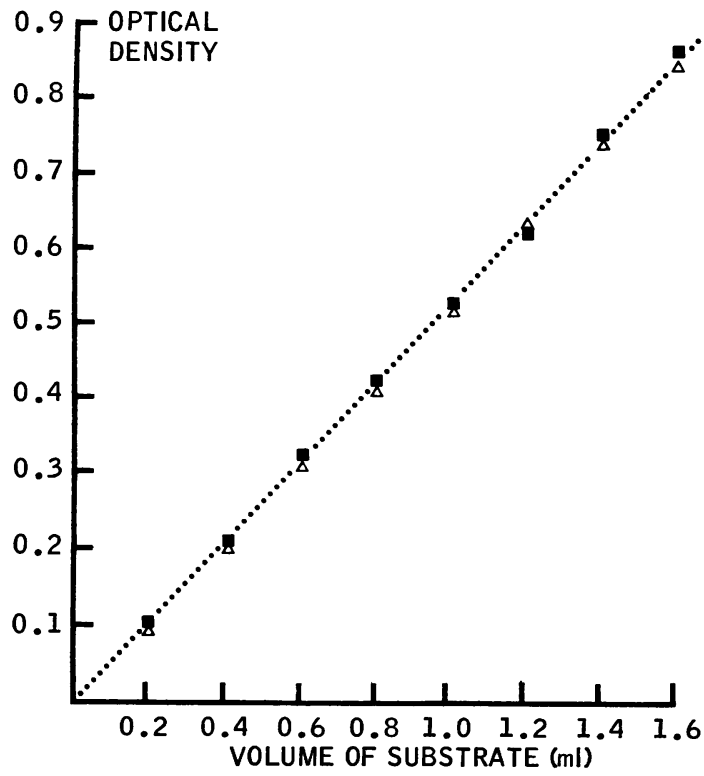

FIG. 1. Comparison of the optical densities of the iodine colours given by starch substrates prepared with and without dimethylsulphoxide. Different volumes of buffered starch solution and saline were made up to $9.6 \mathrm{ml}$ with water, $0.4 \mathrm{ml}$ of iodine added, and the optical densities read immediately. $\square=$ dimethylsulphoxide starch. $\Delta=$ aqueous starch. and further diluted with water to give the usual concentrations of starch and buffer. These solutions were then used to determine the amylase activity of a number of sera and the results are shown in Table I. Slight increases in activity occur in the presence of DMSO but these are not proportional to the concentration of DMSO over a wide range.

\section{TABLE I}

EFFECT OF DIMETHYLSULPHOXIDE ON HYDROLYSIS OF STARCH BY AMYLASE

\begin{tabular}{|c|c|}
\hline $\begin{array}{l}\text { Final Concentration of } \\
\text { Dimethylsulphoxide }(\mathrm{ml} / 100 \mathrm{ml} \\
\text { Substrate })\end{array}$ & $\begin{array}{l}\text { Percentage of } \\
\text { Optical Dens }\end{array}$ \\
\hline $\begin{array}{r}0.0 \\
1.0 \\
2.0 \\
5.0 \\
10.0 \\
20.0 \\
30.0\end{array}$ & $\begin{array}{l}100 \cdot 0 \\
104 \cdot 1 \\
100 \cdot 2 \\
107.8 \\
111 \cdot 5 \\
102.1 \\
113.5\end{array}$ \\
\hline
\end{tabular}
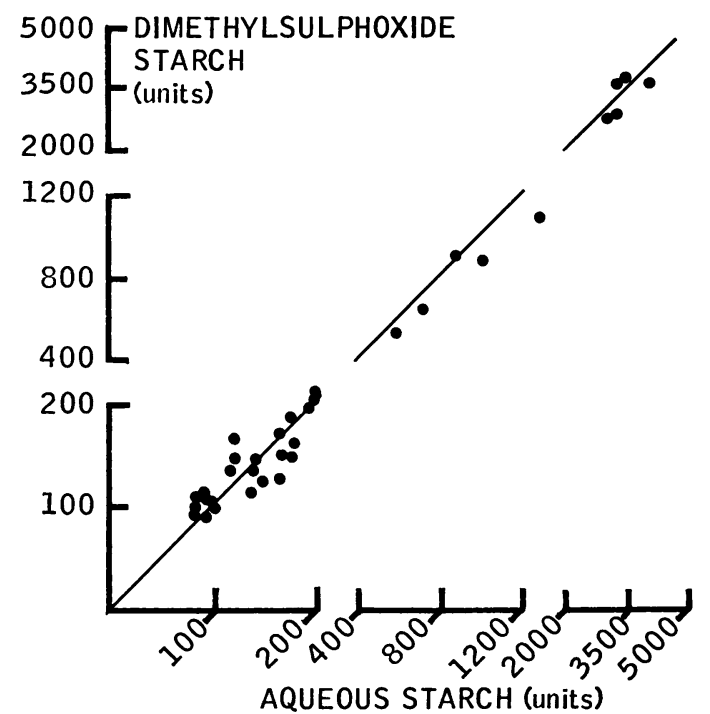

FIG. 2. Comparison of the amylase activities obtained with 36 normal and pathological sera using aqueous starch substrate or dimethylsulphoxide substrate.

COMPARISON OF SERUM AMYLASE ACTIVITY USING AQUEOUS STARCH AND DIMETHYLSULPHOXIDE STARCH Results for amylase determinations on 36 normal and pathological sera ranging from 81 to 3,800 Somogyi units made by both techniques are shown in Figure 2. The activities with DMSO starch were slightly higher than with the aqueous preparation, the mean increase being $3.7 \%$.

STABILITY OF SOLUTIONS OF STARCH IN DIMETHYLSULPHOXIDE The blue starch iodine colour is 
proportional to the concentration of starch over a wide range and degradation of starch can be detected by measurement of the optical density of the substrate blank over a period. Control (substrate blank) optical densities of dimethylsulphoxide starch preparations kept for up to six months are shown in Table II. No appreciable fall in optical density occurred over the period. Amylase activities were also determined using substrate prepared from DMSO starch which had been stored for one year and the results are shown in Table III. The activities were not significantly different from those found using a fresh preparation.

In these experiments the stock solutions were stored in glass bottles at room temperature and

\section{TABLE II}

OPTICAL DENSITIES OF SUBSTRATE CONTROLS PREPARED FROM THREE SAMPLES OF DMSO STARCH STORED AT ROOM TEMPERATURE FOR UP TO SIX MONTHS

\begin{tabular}{ccc} 
DMSO Starch Samples & $\begin{array}{l}\text { Age } \\
(\text { Weeks })\end{array}$ & Optical Density \\
\hline B & 0 & 0.530 \\
& 9 & 0.520 \\
& 12 & 0.530 \\
C & 24 & 0.535 \\
& 0 & 0.535 \\
& 4 & 0.535 \\
& 5 & 0.520 \\
& 9 & 0.530 \\
D & 21 & 0.525 \\
& 0 & 0.555 \\
& 4 & 0.580 \\
& 16 & 0.540
\end{tabular}

TABLE III

AMYLASE ACTIVITY OF SERUM DETERMINED ON THREE DIFFERENT STARCH SUBSTRATE SOLUTIONS ${ }^{1}$

\begin{tabular}{|c|c|c|c|}
\hline \multirow{2}{*}{$\begin{array}{l}\text { Serum } \\
\text { Sample }\end{array}$} & \multicolumn{3}{|c|}{ Substrate ${ }^{2}$} \\
\hline & $A$ & $\boldsymbol{B}$ & $C$ \\
\hline $\begin{array}{c}1 \\
1 \\
1 \\
1 \\
1 \\
1 \\
1 \\
2 \\
2 \\
\text { Mean }\end{array}$ & $\begin{array}{l}167 \\
156 \\
167 \\
156 \\
136 \\
146 \\
167 \\
207 \\
214 \\
168 \cdot 4\end{array}$ & $\begin{array}{l}159 \\
162 \\
162 \\
162 \\
182 \\
162 \\
169 \\
194 \\
192 \\
171 \cdot 6\end{array}$ & $\begin{array}{l}173 \\
185 \\
163 \\
166 \\
163 \\
151 \\
173 \\
210 \\
210 \\
177 \cdot 1\end{array}$ \\
\hline \multicolumn{4}{|c|}{ 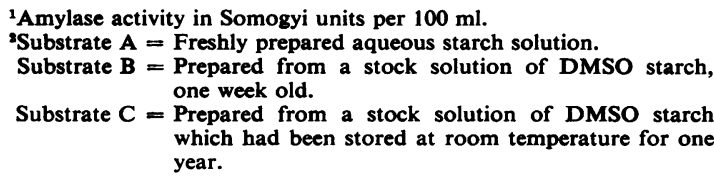 } \\
\hline
\end{tabular}

remained water clear. No sterile precautions werẹ. taken during preparation and storage.

Dimethylsulphoxide starch which has been dilute with phosphate benzoate buffer behaves similarli to the Wootton (1964) preparation on keeping. The optical density of the control falls slowly over period of weeks when the solution is stored at $4^{\circ} \mathbb{E}$ and is in use daily. Occasionally a marked fall iक optical density of the control occurred (for example from 0.520 to 0.330 in 26 days).

\section{DISCUSSION}

A stock starch preparation which is stable for manỹ months and which can be diluted in a few minutes to give a working substrate has advantages over os buffered substrate which is liable to erratic degrada $f$ tion. Dimethylsulphoxide has been reported to inhibit cholinesterase (Sams and Carroll, 1966) but has little effect on amylase at many times the cono centration used in the substrate in this method. The slight apparent activation of the enzyme is not pro응 portional to the concentration of the DMSO ove? a wide range and may well be an effect on the system rather than the enzyme per se.

The stock solution of starch in dimethylsulphoxide has been shown to be stable both with respect to iodine reaction and as an amylase substrate. The dilute buffer substrate behaves similarly to the aqueous preparation and should not be kept fot longer than one month as is recommended by Wootton (1964). If amylase estimations are madew infrequently it is better to dilute the stock solution freshly for each batch of estimations. The range of normal values for the method given by Caraway. (1959) of 60 to 160 Somogyi units was extended by Wootton (1964) who took the normal range to be upo to 200 units. If this figure is taken as the upper limip. of normal the slight 'activation' produced byS dimethylsulphoxide will not alter this limit signiき ficantly.

\section{REFERENCES}

Caraway, W. T. (1959). Amer. J. clin. Path., 32, 97.

Gomori, G. (1957). Ibid., 27, 714.

Marsters, R. W., Kinney, T. D., and Lin, K. Y. (1960). Clin. Chem. N 6, 130 .

Pimstone, N. R. (1964). Ibid., 10, 891.

Reif, A. E., and Nabseth, D. C. (1962). Ibid., 8, 113.

Rice, E. W. (1959). Ibid., 5, 592.

Sams, W. M., Jr, and Carroll, N. V. (1966). Nature (Lond.), 212, 4050

Wilding, P. (1963). Clin. chim. Acta, 8, 918.

Wootton, I. D. P. (1964). Micro-Analysis in Medical Biochemistry, 4th ed., p. 106. Churchill, London. 